\title{
Sensitivity of seedling growth to phosphorus supply in six tree species of the Australian Great Western Woodlands
}

Article

Accepted Version

Williams, A., George, S., Birt, H., Daws, M. and Tibbett, M. (2019) Sensitivity of seedling growth to phosphorus supply in six tree species of the Australian Great Western Woodlands. Australian Journal of Botany, 67 (5). pp. 390-396. ISSN 00671924 doi: https://doi.org/10.1071/BT18247 Available at https://centaur.reading.ac.uk/85122/

It is advisable to refer to the publisher's version if you intend to cite from the work. See Guidance on citing.

To link to this article DOI: http://dx.doi.org/10.1071/BT18247

Publisher: CSIRO

All outputs in CentAUR are protected by Intellectual Property Rights law, including copyright law. Copyright and IPR is retained by the creators or other copyright holders. Terms and conditions for use of this material are defined in the End User Agreement.

www.reading.ac.uk/centaur 
Central Archive at the University of Reading

Reading's research outputs online 


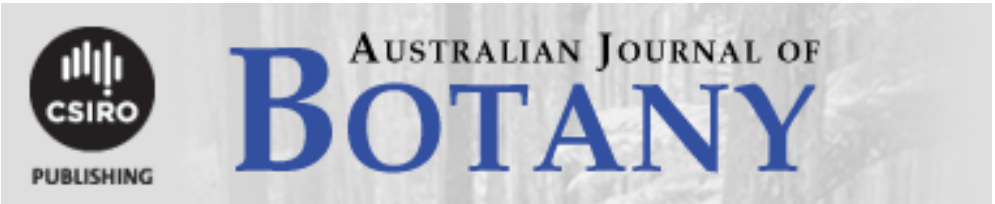

\section{Sensitivity to phosphorus supply of six tree seedlings of the Australian Great Western Woodlands}

\begin{tabular}{|r|l|}
\hline Journal: & Australian Journal of Botany \\
\hline Manuscript ID & BT18247.R1 \\
\hline Manuscript Type: & Research paper \\
\hline Date Submitted by the \\
Author: & n/a \\
\hline Complete List of Authors: & $\begin{array}{l}\text { Williams, Andrea; Jim's Seeds, Weeds \& Trees } \\
\text { George, Suman; University of Western Australia Faculty of Science } \\
\text { Daws, Matt; University of reading, School of Agriculture, Policy and } \\
\text { Development } \\
\text { Birt, Henry; University of Queensland School of Agriculture and Food } \\
\text { Sciences } \\
\text { Tibbett, Mark; University of Reading, }\end{array}$ \\
\hline Keyword: & Phosphorus, Eucalypts, Acacia spp., Seedling development, Growth \\
\hline
\end{tabular}

\section{SCHOLARONE \\ Manuscripts}


Phosphorus is routinely applied to soils in tree-based restoration schemes, despite the balance between beneficial and deleterious effects being poorly understood. For six woody species from the Great Western Woodlands of Western Australia, growth increased in response to low concentrations of applied phosphorus. At higher phosphorus concentration, growth either plateaued or declined. Applied phosphorus may have different and unpredictable effects on native species suggesting caution when applying high rates of phosphorus in a field-setting. 
2 Sensitivity of seedling growth to phosphorus supply in six tree species of the Australian

\section{Great Western Woodlands}

4

5

6 Andrea Williams ${ }^{\mathrm{a}}$, Suman George ${ }^{\mathrm{b}}$, Henry W. G. Birt ${ }^{\mathrm{c}, \mathrm{d}}$, Matthew I. Daws ${ }^{\mathrm{d}}$, Mark Tibbett ${ }^{\text {d.e** }}$

7

$8 \quad$ JJim's Seeds, Weeds \& Trees, Boulder, Western Australia

9 bSchool of Agriculture and Environment, University of Western Australia, Crawley, WA, 10 Australia

11 'School of Agriculture and Food Sciences, The University of Queensland, Qld, Australia.

$12{ }^{\mathrm{d} C e n t r e}$ for Agri-Environmental Research and Soil Research Centre, School of Agricultural

13 Policy and Development, University of Reading, Berkshire RG6 6AR, UK

14 eSchool of Biological Sciences, University of Western Australia, Crawley, WA, Australia

$16 *$ Author for correspondence

17

18 Email: m.tibbett@reading.ac.uk 


\section{Abstract}

2 Many Australian native plants from regions with ancient, highly weathered soils have specialised adaptations for acquiring phosphorus (P) and can exhibit negative effects of

4 excess P supply on growth and survival. Despite this, fertiliser (including P) is routinely

5 applied in post-mining and other restoration schemes. In this study we investigated the effect

6 of a range of applied $\mathrm{P}$ on the growth and tissue $\mathrm{P}$ concentrations for six woody species from

7 the Great Western Woodlands (GWW) of Western Australia, a region that it not only biodiverse, but that has experienced significant levels of mining related activities. Our data

9 from a pot-based experiment show that all six species exhibited greater growth with increased $\mathrm{P}$ application up to $15 \mathrm{mg} \mathrm{kg} \mathrm{sand}{ }^{-1}$. However, at $\mathrm{P}$ concentrations in excess of $15 \mathrm{mg} \mathrm{kg}^{-1}$, dry mass accumulation did not increase further for three of the species tested. For the other three species, dry mass accumulation declined as the $\mathrm{P}$ concentration increased above $15 \mathrm{mg}$ $\mathrm{kg}^{-1}$. For all of the study species, root and shoot $\mathrm{P}$ concentrations increased as the concentration of applied $\mathrm{P}$ increased. The internal shoot $\mathrm{P}$ concentration, at which dry matter accumulation either plateaued or started to decline, was in the range 1.95 to $3.2 \mathrm{mg} \mathrm{P} \mathrm{g}^{-1} \mathrm{DM}$.

This was approximately 2 to 4 times the concentration found in natural vegetation. These data suggest that in a restoration context, there is a potential risk that, excess $\mathrm{P}$ applcation may decrease plant growth rates for some species. Consequently, the addition of fertiliser to restored sites may have unpredictable impacts on the plant community by directly reducing the growth of some species while increasing the growth of others. We suggest that careful consideration should be given to designing appropriate fertiliser regimes for land restoration schemes in ancient $\mathrm{P}$ deplete landscapes to avoid the risk that fertiliser addition has the unwanted outcome of decreasing growth and survival of the target native species whilst increasing the abundance of unwanted weeds or aggressive pioneer species.

Key words: fertiliser, P accumulation, P-toxicity, P-use efficiency, rehabilitation 


\section{Introduction}

The Great Western Woodlands (GWW) of Western Australia is the largest intact temperate woodland left on earth (Morton 2014). The region hosts a plethora of biodiversity including 3,300 flowering plants, approximately $30 \%$ of Australia's Eucalyptus species and 138 reptile species (Booth 2013). Whilst being a biodiversity hotspot, the GWW also contains rich mineral resources and has been subjected to mining: the GWW have significant geographical overlap with the Western Australian goldfields (Watson et al. 2015). As a result, there is a need for a greater understanding of the growth, physiology and nutrition of native tree species for use in post-mining restoration.

The addition of fertiliser to increase plant growth in newly established post-mining restoration is a common feature of mine restoration programmes both in Australia and elsewhere (e.g. George et al. 2006; Worrall et al. 2007; Standish et al. 2010; Tibbett 2010; Williamson et al. 2011; Zipper et al. 2011; Ortiz et al. 2012; Spain et al. 2019). However, an increasing number of studies suggest that there may be contrasting effects of fertiliser addition on different functional groups of species. For example, addition of phosphorus (henceforth, P-fertiliser) to mine restoration in the Cape Region of South Africa and in SW Western Australia increased the growth of both native and non-native annual species, but either increased mortality or reduced the establishment of slower growing species such as Proteaceae (Holmes 2001; Daws et al. 2013, 2015).

The Cape Floristic Region and SW Western Australia have soils depleted in nutrients, particularly P, due to a preponderance of ancient, highly weathered soils (Handreck 1997; Lambers et al. 2008;). Consequently, many plant species in these environments have specialised adaptations, such as root clusters, mycorrhizal symbioses and exudation of carboxylases and phosphatases, for acquiring P (Lambers et al. 2006, 2008). Furthermore, a number of Australian plant species occurring on nutrient impoverished soils have a limited 
1 ability to regulate P-uptake when the P-supply is increased. These species are sensitive to P-

2 toxicity when supplied with P concentrations above those that they naturally experience in soil (Shane et al. 2004a; Handreck 1991; Lambers et al. 2002; Pang et al. 2010; de Campos et

4 al. 2013), due potentially to the loss of low affinity transporter systems (Huang et al. 2011).

5 Consequently, when undertaking environmental restoration in environments with naturally

6 nutrient deficient soils, there may not just be little benefit to growth from adding (P-)

7 fertiliser, but also potential negative effects on growth and survival for a range of species.

8 However, many of these studies on responses to applied-P have either focused on Proteaceae

9 or on species from the naturally P-deficient soils of SW Western Australia (or both). As a

10 result, there is a need to investigate plant responses to applied-P in other nutrient deficient

11 regions.

The soils of the GWW are also typically deficient in P and consequently, the application of fertiliser, particularly $\mathrm{P}$, to increase plant growth is viewed as a requirement to increase growth and establishment in post-mining restoration in this region (e.g. KCGM 2015). However, there is minimal available data of the effects of P-addition, on species from the GWW, particularly with regard to potential problems such as P-toxicity. Consequently, our current study was established to determine how tree seedlings native to the Australian GWW respond to a wide range of $\mathrm{P}$ concentrations. For six species we tested, (1) their response to low-P (P-response efficiency), (2) their capacity to grow and regulate P-uptake at high-P, where toxicity might depress growth, and (3) the response of root and shoot tissue $\mathrm{P}$ concentrations to applied $\mathrm{P}$. 


\section{$1 \quad$ Materials and methods}

2

3

4

5

6

\section{Plant material and experimental design}

Six tree and shrub species from three genera, all native to the GWW of Western Australia, were used in the current study (see Table 1). All six species are used in post-mining restoration in this region. This study was carried out in a shade house established in Kalgoorlie in the South Western Interzone in the Coolgardie Botanical district in WA, Australia $\left(30^{\circ} 44^{\prime} 56^{\prime \prime} \mathrm{S}, 121^{\circ} 27^{\prime} 57^{\prime \prime} \mathrm{E}\right.$; Beard 1990) for the study. All seeds used were subjected to appropriate pre-treatments (e.g. application of smoke water) to enhance germination, following which the seeds were planted into a sand substrate.

Seeds were sown in October 2006 with seedling growth occurring from November 2006 to April 2007 for a total period of 136 days. This time of year was chosen for the experiment as it is the optimal time for growth in this region. Temperatures during this period ranged from 13.6 to $36.9^{\circ} \mathrm{C}$. Temperature in the shade house was not regulated and reflect the range of temperatures typical for the GWW area.

For each of the six species, four replicate pots containing $5 \mathrm{~kg}$ of yellow river sand were established at each of seven phosphorus concentrations $(0,4,8,15,30,90,150 \mathrm{mg} \mathrm{P}$ $\mathrm{kg}^{-1}$ sand). The sand contained $1 \mathrm{mg} \mathrm{kg}^{-1}$ Colwell $\mathrm{P}$ and $\mathrm{N}$ was below detection limits. $\mathrm{P}$ was added in the treatments as $\mathrm{KH}_{2} \mathrm{PO}_{4}$. Additional nutrients were provided in two aliquots throughout the experiment to give a nutrient concentration of: ( $\mathrm{mg} \mathrm{kg}^{-1}$ soil) $\mathrm{K} 62.8$, S 39.4, Ca 40.9, Mg 7.9, Cu 0.53, Zn 2.86, Mn 3.29, B 0.12, Co 0.09, Na 0.04, Mo 0.08 and N 33.N was added in the form of $\mathrm{NH}_{4} \mathrm{NO}_{3}$ and sulphur in $\mathrm{MgSO}_{4} 7 \mathrm{H}_{2} \mathrm{O}$. Soil moisture was maintained throughout the experiment by adding deionised water to match weight loss. Plants were checked regularly for pests and signs of infection.

\section{Plant measurements}


1 At the end of the growth period (136 days after the start of the experiment), plants were

2 carefully removed from the growing medium. Roots were washed with water; the plants were

3 then separated into roots and shoots. Morphological features were noted and then samples

4 were then oven dried at $70^{\circ} \mathrm{C}$ to a constant weight. Sub samples were digested using nitric

5 perchloric acid (1:3) and $\mathrm{P}$ was measured using the heteropoly-molybdenum method (Ames 6 1966).

For each species, growth responses (total plant dry mass) to applied-P were calculated at $\mathrm{P}$ supplies of 4, 8, 15, 30, 90 and $150 \mathrm{mg} \mathrm{P} \mathrm{kg}^{-1}$. Following the methodology in Pang et al. (2010), these growth responses were calculated for the following ranges of P application: 1) subtracting total dry mass for the $0 \mathrm{mg} \mathrm{P} \mathrm{kg}{ }^{-1}$ treatment from dry mass at $4 \mathrm{mg} \mathrm{P} \mathrm{kg}^{-1} ; 2$ ) subtracting dry mass at $4 \mathrm{mg} \mathrm{P} \mathrm{kg}^{-1}$ treatment from dry mass at $8 \mathrm{mg} \mathrm{P} \mathrm{kg}^{-1}$; 3) subtracting dry mass at $8 \mathrm{mg} \mathrm{P} \mathrm{kg}^{-1}$ treatment from dry mass at $15 \mathrm{mg} \mathrm{P} \mathrm{kg}^{-1}$; 4) subtracting dry mass at $15 \mathrm{mg} \mathrm{P} \mathrm{kg}{ }^{-1}$ treatment from dry mass at $30 \mathrm{mg} \mathrm{P} \mathrm{kg}^{-1}$; 5) subtracting dry mass at $30 \mathrm{mg} \mathrm{P}$ $\mathrm{kg}^{-1}$ from dry mass at $90 \mathrm{mg} \mathrm{P} \mathrm{kg}{ }^{-1}$, and 6) subtracting dry mass at $90 \mathrm{mg} \mathrm{P} \mathrm{kg}^{-1}$ from dry mass at $150 \mathrm{mg} \mathrm{P} \mathrm{kg}^{-1}$. The increments in plant dry mass were then divided by the difference between amounts of P supplied to provide P-response efficiency values (dry mass produced per unit of applied $\mathrm{P}$ in each of the six ranges of $\mathrm{P}$ application, such that for each incremental increase in applied P:

$$
\mathrm{P} \text { response efficiency }=\Delta \mathrm{P} \text { in dry mass } / \Delta \text { applied soil } \mathrm{P} \text {. }
$$

\section{Statistical analysis}

This investigation followed a two factor (concentration of applied-P and species) randomised block design. Two-way ANOVA implemented in Minitab 14 was used to assess, for each species, whether there were effects of increasing external P concentration on either tissue 
Williams et al.

1 specific (root versus shoot) dry mass or P concentration. Data did not require transformation

2 prior to analyses as the assumptions of ANOVA with respect to normality and homogeneity

3 of variances were met. 


\section{$1 \quad$ Results}

\section{$2 \quad$ Plant biomass}

3 Plant growth in the absence of applied-P varied between species with total dry mass (root

4 plus shoot) ranging from 0.14 to $1.42 \mathrm{~g}$ for Acacia acuminata and Eucalyptus torquata,

5 respectively (Fig. 1). Across the six species there was no correlation between seed mass and

6 maximum plant dry mass in the absence of applied-P $(P>0.05)$. Root biomass of Atriplex

$7 \quad$ nummularia, Atriplex vesicaria and Maireana triptera increased significantly as external P

8 increased from 0 to $15 \mathrm{mg} \mathrm{kg}^{-1}$ and then exhibited no further change as $\mathrm{P}$ increased further up

9 to $150 \mathrm{mg} \mathrm{kg}^{-1}$ (Fig. $\left.1 \mathrm{c}, \mathrm{d}, \mathrm{f}\right)$. For Acacia accuminata, Acacia hemiteles and Eucalyptus

10 torquata there was little change in root biomass as soil $\mathrm{P}$ concentration increased (Fig. 1

$11 \mathrm{a}, \mathrm{b}, \mathrm{e})$.

For all six species, shoot biomass increased as the applied $\mathrm{P}$ concentration increased

from 0 to $15 \mathrm{mg} \mathrm{kg}^{-1}$ (Fig. 1). However, at $\mathrm{P}$ concentrations greater than $15 \mathrm{mg} \mathrm{kg}^{-1}$ there was either no further increase in shoot biomass (Atriplex nummularia, Atriplex vesicaria and Acacia acuminata; Fig. 1a,c,d) or biomass declined with increasing P (Maireana triptera,

Eucalyptus torquata and Acacia hemiteles; Fig. 1b,e,f). For each of the six individual species the effect of increasing external $\mathrm{P}$ on overall dry mass was significant (Two-way Anova, $P<$ 0.05). In addition for all six species shoot biomass was significantly higher than root biomass (Two-way Anova, $P<0.05$ ).

\section{Tissue P concentration}

For all six species there was a significant effect of increasing concentrations of external $\mathrm{P}$ on root and shoot $\mathrm{P}$ concentrations (Two-way Anova, $P<0.001$; Fig. 2), with little exogenous $\mathrm{P}$ was required to give foliar P concentration considerably above level found in the natural flora. For Acacia acuminata, Acacia hemitelata and Eucalyptus torquata, tissue P 
1 concentrations exhibited little response to $\mathrm{P}$ concentration in the growing medium until the $\mathrm{P}$

2 concentration was approximately $15 \mathrm{mg} \mathrm{kg}^{-1}$. Beyond this external concentration, both root and shoot $\mathrm{P}$ concentrations continued to increase with increasing applied-P (Fig. 2a,b,e). In contrast, for Atriplex nummularia, Atriplex vesicaria and Maireana triptera, tissue $\mathrm{P}$ concentrations increased in response to the lowest level of applied $\mathrm{P}\left(4 \mathrm{mg} \mathrm{kg}^{-1}\right)$. There were also significant differences in P concentrations between root and shoot tissues (Two-way

7 Anova, $P \leq 0.008$ ). The interaction between tissue type and external P-concentration was significant (Two-way Anova, $P \leq 0.001$ ) for all species, except Atriplex nummularia, indicating differences in the response of root and shoot $\mathrm{P}$ concentration to increasing external P. For two of the species (Atriplex nummularia and Atriplex vesicaria), $\mathrm{P}$ concentrations were significantly higher in shoot than root tissue (Fig. 2a,d). For Acacia acuminata, root $\mathrm{P}$ accumulation was significantly higher than that of its shoot $\mathrm{P}$, while limited significant differences in root and shoot $\mathrm{P}$ were observed for Acacia hemiteles, Eucalyptus torquata and Maireana triptera. At maximum total dry mass (approximate external P concentration of 15 $\mathrm{mg} \mathrm{kg}^{-1}$ ), shoot $\mathrm{P}$ concentrations ranged from 1.95 (Atriplex nummularia) to $3.72 \mathrm{mg} \mathrm{g}^{-1} \mathrm{DM}$ (Acacia acuminata). For Acacia hemitelata, Eucalyptus torquata and Maireana triptera a decline in biomass with increasing applied $\mathrm{P}$ coincided with shoot $\mathrm{P}$-concentrations in excess of $2.47,2.1$ and $3.2 \mathrm{mg} \mathrm{g}^{-1} \mathrm{DM}$, respectively.

\section{P-response efficiency}

P-response efficiency differed among the 6 species. Atriplex nummularia and Eucalyptus torquata showed the highest apparent P-response efficiency as $\mathrm{P}$ increased from 0 to $4 \mathrm{mg} \mathrm{kg}-$ ${ }^{1}$ sand while Acacia hemiteles showed the lowest apparent P-response efficiency (Fig. 3). When applied $\mathrm{P}$ increased from 4 to $8 \mathrm{mg} \mathrm{kg}^{-1}$, Atriplex nummularia still had the highest Presponse efficiency, but the order for the other species changed: Maireana triptera now had 
Williams et al.

1 the second highest P-response efficiency whilst Eucalyptus torquata was ranked fourth of the

2 six species. When applied P increased further, P-response efficiency declined in all species

3 and was either close to zero or negative at the highest $\mathrm{P}$ concentrations (Figure 3 ).

4 


\section{Discussion}

2 An increase in external P-supply resulted in an increased biomass for our study species only

when the P supply was relatively low. At higher P supply, there was either no further increase in biomass or biomass declined. Similar patterns have been observed previously for a range of Australian species from severely nutrient-impoverished environments (Grundon 1972; Groves and Keraitis 1976; Handreck 1997; Pang et al. 2010; de Campos et al. 2013). Maximum dry mass of our study species was generally observed at an external $\mathrm{P}$ concentration of $15 \mathrm{mg} \mathrm{kg}^{-1}$ sand. In addition, for all the study species P-response efficiency values were positive at low $\mathrm{P}$-application rates $\left(\leq 15 \mathrm{mg} \mathrm{P} \mathrm{kg}^{-1}\right)$ indicating a continuing growth response to increasing $\mathrm{P}$ application. However, above $15 \mathrm{mg} \mathrm{P} \mathrm{kg}^{-1}$, values were either close to zero or negative suggesting that there is no further incremental benefit to growth from applying $\mathrm{P}$ at rates greater than $15 \mathrm{mg} \mathrm{kg}^{-1}$. Similarly, Ryan et al. (2009) recorded maximum root and shoot dry mass for the Australian native Ptilotus polystachys at 15 mg P kg-1 soil. Pang et al. (2010), also observed maximum dry mass for four perennial legumes at an external $\mathrm{P}$ concentration of $12 \mathrm{mg} \mathrm{kg}^{-1}$ soil and for their remaining 7 species, maximum dry mass was achieved at $24 \mathrm{mg} \mathrm{kg}^{-1}$ soil. In addition, Pang et al. (2010) reported that for 8 of their study species, when the external P concentration was greater than that required to obtain maximum dry mass, total dry mass was reduced, even though most of the species did not exhibit obvious visual symptoms of P-toxicity.

Significantly higher P-concentrations were observed in roots than shoots of Acacia acuminata. This may reflect an ability to allocate and store excess $\mathrm{P}$ within the root tissue. Such a mechanism has been shown in several species of Proteaceae (Jeschke and Pate 1995; Shane et al. 2004b; Shane and Lambers 2006) and may serve to buffer the leaves and shoots from the effects of excess $\mathrm{P}$ as well as enabling $\mathrm{P}$ remobilisation for subsequent growth thereby contributing to highly efficient $\mathrm{P}$ use. 
For the three species that exhibited a negative effect of elevated levels of external-P

on biomass accumulation, the shoot $\mathrm{P}$ concentrations at which these negative effects occurred

were at the lower end of the range of leaf and shoot $\mathrm{P}$ concentrations for P-toxicity compiled previously ( 0.9 to $47 \mathrm{mg} \mathrm{P} \mathrm{g}^{-1}$ dry mass; Shane et al. 2004b). However, the range of values

5 for shoot $\mathrm{P}$ at which negative effects were observed (2.1 to $\left.3.2 \mathrm{mg} \mathrm{g}^{-1} \mathrm{DM}\right)$ are in close agreement with those reported for P-toxicity in Eucalyptus marginata (1.8 to 5.5mg $\mathrm{P} \mathrm{g}^{-1}$ DM) by Kariman et al. (2014). One possible explanation for the difference between our current values and those reported in Shane et al. (2004b) is that many of the values reported by Shane and co-workers are for the onset of visible symptoms of P-toxicity (e.g. necrosis): our results indicate the onset of a negative effect on plant growth.

It is also interesting to note that the values of shoot $\mathrm{P}$ that we report at the lowest external P application rates were consistent with concentrations recorded for plants in the same families harvested from the natural environment (Foulds 1993). In fact, over a wide range of habitats, Foulds (1993) only very occasionally found tissue P concentration over 1 $\mathrm{mg} \mathrm{g}^{-1} \mathrm{P}$. In the current study, we found only small levels of fertilisation caused $\mathrm{P}$ concentrations to rise above values found in natural ecosystems, with peak concentrations, after $\mathrm{P}$ application approximately 2-4 times that found in native habitats. seed mass (e.g. Westoby et al. 1996), this was not the case over the 136 days of growth in our current study, possibly because seedling growth was no longer relying on stored seed reserves. Indeed, despite having a seed mass approximately one third of that of the largest seeded species, Atriplex nummularia achieved the greatest dry mass. In addition, Atriplex nummularia had the highest P-response efficiency values of our six study species, and a higher P-use efficiency than all 11 perennial herbaceous legumes that were investigated by Pang et al. (2010) as potential pasture legumes for use conditions of under low P availability. 
1 While high P-use efficiency between soil $\mathrm{P}$ concentrations of 0 and $4 \mathrm{mg} \mathrm{kg}^{-1}$ might relate to seed $\mathrm{P}$ concentrations, $\mathrm{P}$-use efficiency was also high between $4-8$ and $8-15 \mathrm{mg} \mathrm{P} \mathrm{kg}^{-1}$. Thus, Atriplex nummularia appears to have an ability to acquire $\mathrm{P}$ and use it efficiently for biomass production even in low $\mathrm{P}$ environments. Consequently, this species has potential for rapid growth and establishment in the low $\mathrm{P}$ environments of post mining restored sites.

Three of the study species (the two Acacia species and Eucalyptus torquata) were able to maintain their internal root and shoot P-concentrations at a constant level at low, but not at high, external $\mathrm{P}$ concentrations. This is similar to the findings by de Campos et al. (2013) who reported the ability of two Acacia species (Acacia truncata and Acacia xanthina) to regulate internal P-concentrations at low external P-concentrations. However, at higher external P concentrations root and shoot P-concentrations increased in all six of our study species. Similar to our current study, de Campos et al. (2013) also reported a mixed result in terms of the effect of increasing P on biomass accumulation: Acacia truncata was unresponsive in terms of biomass to high $\mathrm{P}$, whilst Acacia xanthina exhibited declining biomass as $\mathrm{P}$ increased. These results suggest that the growth response to elevated $\mathrm{P}$, even within co-occurring members of a genus, is unpredictable as also reported for the genus Banksia (de Campos et al. 2013).

Our data suggest that even low concentrations of soil $\mathrm{P}$ can have negative effects on plant growth for a range of woody species from the GWW. Based on a soil dry bulk density of $1 \mathrm{~g} \mathrm{~cm}^{-3}$ and applied $\mathrm{P}$ being limited to the top $100 \mathrm{~mm}$ of soil, the concentrations at which either negative effects were observed, or growth showed no further response (15 or $30 \mathrm{mg} \mathrm{P}$ $\mathrm{kg}^{-1}$ soil dependent on species), are equivalent to field application rates of 15 or $30 \mathrm{~kg} \mathrm{P} \mathrm{ha-1.}$ These application rates are at the low end of those used in many mine site restoration programmes: 25-80 kg P ha-1 are commonly applied (e.g. Holmes 2001; Spain et al. 2015; Standish et al. 2015; KCGM 2015). Consequently, the rates of $\mathrm{P}$ applied to mine restoration 
1 have the potential to reduce, rather than increase, growth of some species. While fungal

2 associations can moderate some of the negative effects of applied-P for some species

3 (Kariman et al. 2014), the application of $\mathrm{P}$ has the potential to change the outcome of

4 competitive interactions by differentially affecting growth of individual species.

Applied P can also result in an increased abundance of weeds in restored sites

6 (Holmes 2001; Daws et al. 2013, 2015). For example, in five-year-old restored jarrah forest

7 in Western Australia weed density increased from close to zero to more than 5 stems $\mathrm{m}^{-2}$ as

8 the P-application rate increased from 0 to $80 \mathrm{~kg} \mathrm{ha}^{-1}$ (Daws et al. 2015). Negative effects of

9 applied-P on plant growth have also been reported in previous studies of mine restoration

10 where applied-P increased mortality or reduced abundance for longer-lived, slow growing

11 species (e.g. Holmes 2001; Daws et al. 2013, 2015). However, in these field-based studies it was not possible to determine if the reduced performance of native species resulted from increased competition with weed species, direct negative effects of applied-P on growth, or both. Nonetheless, our current results support the hypothesis that fertiliser application may negatively affect the competitiveness of some species by actually reducing their growth rates. When combined with applied-P increasing the growth and competitiveness of other species (e.g. weeds and annuals), this introduces an important consideration for the use of applied-P in the restoration of natural plant communities.

\section{Conclusions}

21 For six plant species from the GWW we found that while low levels of applied-P increased plant growth, above an application rate of $15 \mathrm{mg} \mathrm{kg}^{-1}$ effects on plant growth became unpredictable: growth either declined or showed no further response to increasing external P concentrations. Overall our data suggest that careful consideration should be given to designing appropriate fertiliser regimes for restored sites to avoid the risk that fertiliser 
1 addition has the unwanted outcome of decreasing growth and survival of the target native

2 species whilst increasing the abundance of weeds.

\section{Acknowledgements}

5 The completion of this work was supported by the Building Outstanding Impact Support

6 Programme H\&F38: Restoring biodiversity to phosphorus sensitive forests. we are grateful

7 for the seeds and facilities provided by Jim's Seeds Weeds \& Trees Pty Ltd.

\section{Conflicts of Interest}

10 The authors declare no conflict of interest.

\section{References}

Ames BN (1966) Assay of inorganic phosphate, total phosphate and phosphatises. Methods in Enzymology 8, 115-118.

Beard JS (1990) Plant life of Western Australia. Annual Review of Plant Physiology 24, 225 252.

Booth C (2013) Conserving the Great Western woodlands. Wildlife Australia 50, 26.

Daws MI, Standish RJ, Koch JM, Morald TK (2013) Nitrogen and phosphorus fertiliser regime affect jarrah forest restoration after bauxite mining in Western Australia. Appl. Vegetation Science 16, 610-618.

Daws MI, Standish RJ, Koch JM, Morald TK, Tibbett M, Hobbs RJ (2015) Phosphorus fertilisation and large legume species affect jarrah forest restoration after bauxite mining. Forest Ecology and Management 354, 10-17. 
in four species from a phosphorus-impoverished environment. Annals of Botany 111, $445-454$.

Groves RH, Keraitis K (1976) Survival of seedlings of three sclerophyll species at high levels of phosphorus and nitrogen. Australian Journal of Botany 24, 681-690.

Grundon NJ (1972) Mineral nutrition of some Queensland heath plants. The Journal of Ecology 60, 171-181.

Handreck KA (1991) Interactions between iron and phosphorus in the nutrition of Banksia ericifolia L. f. var. ericifolia (Proteaceae) in soil-less potting media. Australian Journal of Botany 39, 373-384.

Handreck KA (1997) Phosphorus requirements of Australian native plants. Australian Journal of Soil Research 35, 241-289.

Holmes PM (2001) Shrubland restoration following woody alien invasion and mining: effects of topsoil depth, seed source, and fertilizer addition. Restoration Ecology 9, 71-84.

Huang CY, Shirley N, Genc Y, Shi S, Langridge P (2011) Phosphate utilization efficiency correlates with expression of low-affinity phosphate transporters and noncoding RNA, IPS1, in barley. Plant Physiology 156, 1217-1229.

Jeschke DW, Pate JS (1995) mineral nutrition and transport in xylem and phloem of Banksia prionotes (Proteaceae), a tree with dimorphic root morphology. Journal of Experimental Botany 46, 895-905.

Kariman K, Barker SJ, Finnegan PM, Tibbett M (2014) Ecto- and arbuscular mycorrhizal symbiosis can induce tolerance to toxic pulses of phosphorus in jarrah (Eucalyptus marginata) seedlings. Mycorrhiza 24, 501-509.

KCGM (2015) Mine closure plan. http://www.superpit.com.au/wpcontent/uploads/2015/05/ESR_ENV_REP321_KCGM-Mine-Closure-Plan2015_03312015.pdf 
1 Lambers H, Juniper D, Cawthray GR, Veneklaas EJ, Martinez-Ferri E (2002) the pattern of carboxylate exudation in Banksia grandis (Proteaceae) is affected by the form of phosphate added to the soil. Plant and Soil 238, 111-122.

Lambers H, Shane MW, Cramer MD, Pearse SJ, Veneklaas EJ (2006) Root structure and functioning for efficient acquisition of phosphorus: matching morphological and physiological traits. Annals of Botany 98, 693-713.

Lambers H, Raven JA, Shaver GR, Smith SE (2008) Plant nutrition-acquisition strategies change with soil age. Trends in Ecology and Evolution 23, 95-103.

Morton S (2014) 'Ten Commitments Revisited: Securing Australia's Future Environment.' (CSIRO Publishing: Collingwood).

Ortiz O, Ojeda G, Espelta JM, Alcaniz JM (2012) Improving substrate fertility to enhance growth and reproductive ability of a Pinus halepensis Mill. afforestation in a restored limestone quarry. New Forests 43, 365-381.

Pang JY, Tibbett M, Denton MD, Lambers H, Siddique KHM, Bolland MDA, Revell CK, Ryan MH (2010) Variation in seedling growth of 11 perennial legumes in response to phosphorus supply. Plant and Soil 328, 133-143.

Ryan MH, Ehrenberg S, Bennett RG, Tibbett M (2009) Putting the P in Ptilotus: a phosphorus-accumulating herb native to Australia. Annals of Botany 103, 901-911.

Shane MW, Szota C, Lambers H (2004a) A root trait accounting for the extreme phosphorus sensitivity of Hakea prostrata (Proteaceae). Journal of Experimental Botany 27, 9911004.

Shane MW, McCully ME, Lambers H (2004b) Tissue and cellular phosphorus storage during development of phosphorus toxicity in Hakea prostrata (Proteaceae). Journal of Experimental Botany 55, 1033-1044. 
1 Shane MW, Lambers H (2006) Systemic suppression of cluster-root formation and net Puptake rates in Grevillea crithmifolia at elevated P supply: a proteacean with resistance for developing symptoms of 'P toxicity'. Journal of Experimental Botany 57, 413-423.

Spain AV, Tibbett, M., Hinz, D.A., Ludwig J.A., Tongway, D.J. (2015) The mining-restoration system and ecosystem development following bauxite mining in a biodiverse environment of the seasonally dry tropics, Northern Territory, Australia. In: Mining in Ecologically Sensitive Landscapes (Ed M. Tibbett), pp. 159-227. CRC Press, Netherlands.

Standish RJ, Daws MI, Gove AD, Didham RK, Grigg AH, Koch JM, Hobbs RJ (2015) Longterm data suggest jarrah-forest establishment at restored mine sites is resistant to climate variability. Journal of Ecology 103, 78-89.

Standish RJ, Tibbett M, Vlahos S, Stokes BA \& Hobbs RJ (2010) The effect of fertiliser on floristic diversity and composition of early-successional jarrah forest restored after bauxite mining in south-western Australia. In: Proceedings of Fifth International Conference on Mine Closure, Santiago, Chile (Eds. A. B. Fourie, M. Tibbett \& J. Wiertz), pp 387-395. Australian Centre for Geomechanics, Perth.

Tibbett, M. (2010) Large-scale Mine Site Restoration of Australian Eucalypt Forests After Bauxite Mining: Soil Management and Ecosystem Development. In: Ecology of Industrial Pollution L.C. Batty \& K. Hallberg, (Eds), pp. 309-326. Cambridge University Press, UK. Watson, AW, Judd S, O’Sullivan W \& Watson JE (2015). A collaborative approach for Mining, Environment Organisations and Traditional Owners to manage and conserve biodiversity in Australia's Great Western Woodlands. In: Mining in Ecologically Sensitive Landscapes (Ed M. Tibbett), pp. 251-263. CRC Press, Netherlands.

Westoby M, Leishman M, Lord J (1996) Comparative ecology of seed size and dispersal. Philosophical Transactions of the Royal Society London B 351, 1309-1318 
1 Williamson JC, Rowe EC, Hill PW, Nason MA, Jones DL, Healey JR (2011) Alleviation of both water and nutrient limitations is necessary to accelerate ecological restoration of waste rock tips. Restoration Ecology 19, 194- 204.

4 Worrall, R. C., Spain, A. V. \& Tibbett, M. (2008) Establishment of Native Tree Species on

5 Coal Tailings - Lessons from Ebenezer Mine, Queensland, Australia. In: Fourie, A.,

6 Tibbett, M. \& Weiersbye, I. \& Dye P. (Eds.). Proceedings of the Third International

7 Seminar on Mine Closure, Johannesburg, South Africa. Pp 739 - 750 Australian Centre for

8 Geomechanics, Perth.

9 Zipper CE, Burger JA, McGrath JM, Rodrigue JA, Holtzman GI (2011) Forest restoration

10 potentials of coal-mined lands in the eastern United States. Journal of Environmental

11 Quality 40, 1567-1577.

12 
1 Table 1. Details of the six study species used in the pot-based experiment of the effect of 2 applied-P on plant growth.

3

\begin{tabular}{llll}
\hline Species & Genus & Seed mass & Growth form \\
& & $\mathbf{( m g )}$ & \\
\hline Acacia acuminata Benth. & Fabaceae & 15.2 & Shrub or tree \\
Acacia hemiteles Benth. & Fabaceae & 22.1 & Shrub \\
Atriplex nummularia Lindl. & Chenopodiaceae & 6.86 & Shrub \\
Atriplex vesicaria Heward ex & Chenopodiaceae & 5.77 & Shrub \\
Benth. & & & Tree \\
Eucalyptus torquata Luehm. & Myrtaceae & 5.18 & Shrub \\
Maireana triptera (Benth.) & Chenopodiaceae & 12.54 & \\
Paul G. Wilson & & & \\
\hline
\end{tabular}

4 


\section{Figure legends:}

2 Fig. 1. The effect of a range of external $\mathrm{P}$ concentrations on dry mass of six woody species

3 from the Great Western Woodlands grown for 136 days in washed river sand at a range of

4 external soil $\mathrm{P}$ concentrations, $\mathrm{n}=4+/$ - standard error of the mean.

5

6 Fig.2. Comparison of root and shoot $\mathrm{P}$ concentrations for six woody species from the Great

7 Western Woodlands grown for 136 days in washed river sand at a range of external $\mathrm{P}$

8 concentrations, $n=4+/$ - standard error of the mean. Dotted lines parallel to the $\mathrm{x}$-axis

9 represent phosphorus concentrations in shoot tissue for the plant families as reported in the

10 natural flora of south west Western Australia (Foulds 1993).

12 Fig.3. Phosphorus-response efficiency (yield response per unit of applied P) measured for six

13 P-application ranges (0-4, 4-8, 8-15, 15-30, 30-90 and 90-150 $\mathrm{mg} \mathrm{P} \mathrm{kg}^{-1}$ sand) for six woody

14 species from the Great Western Woodland, $n=4+/$ - standard error of the mean. 
Williams et al.

\section{$1 \quad$ Figure 1.}

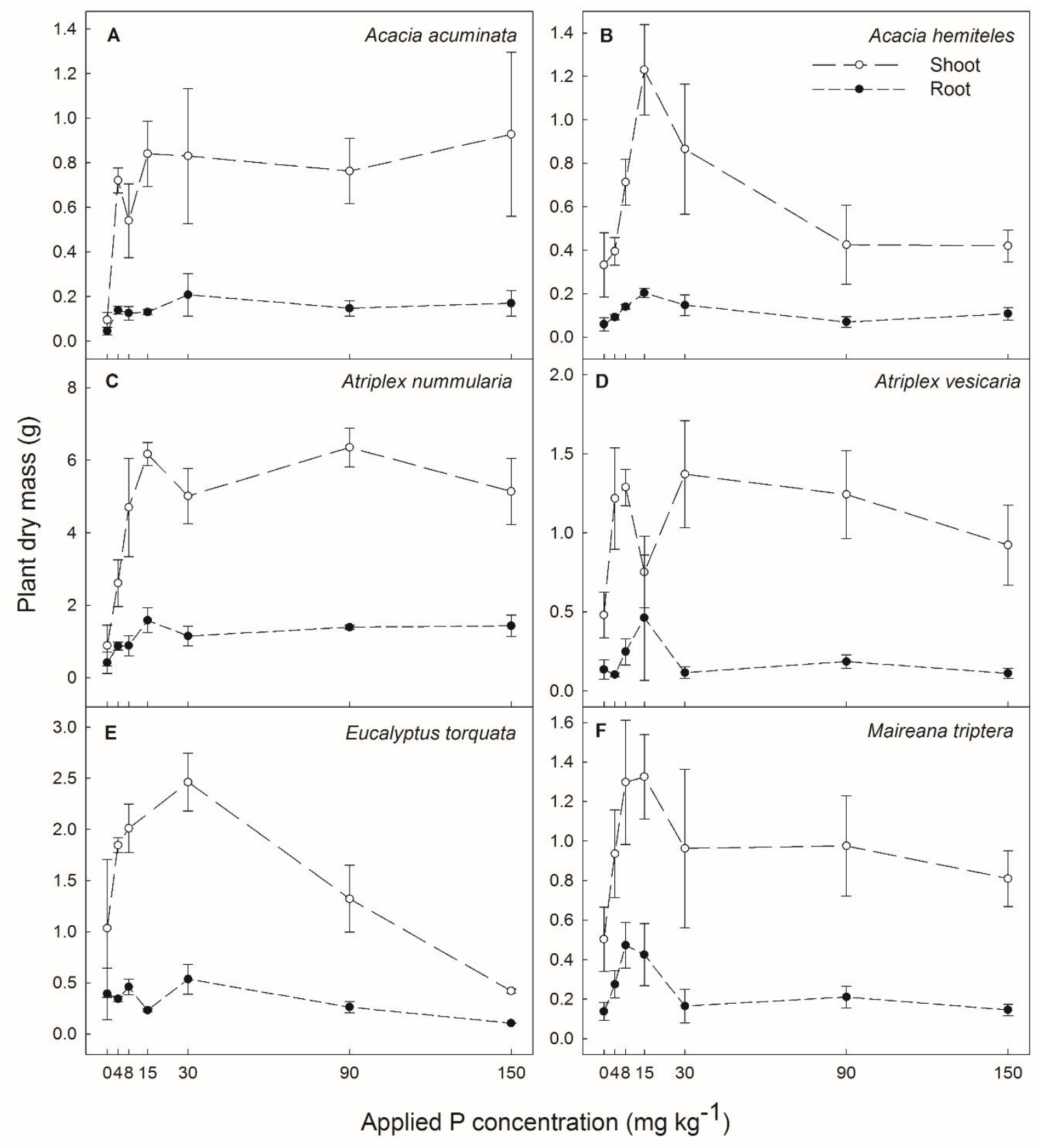




\section{Figure 2.}

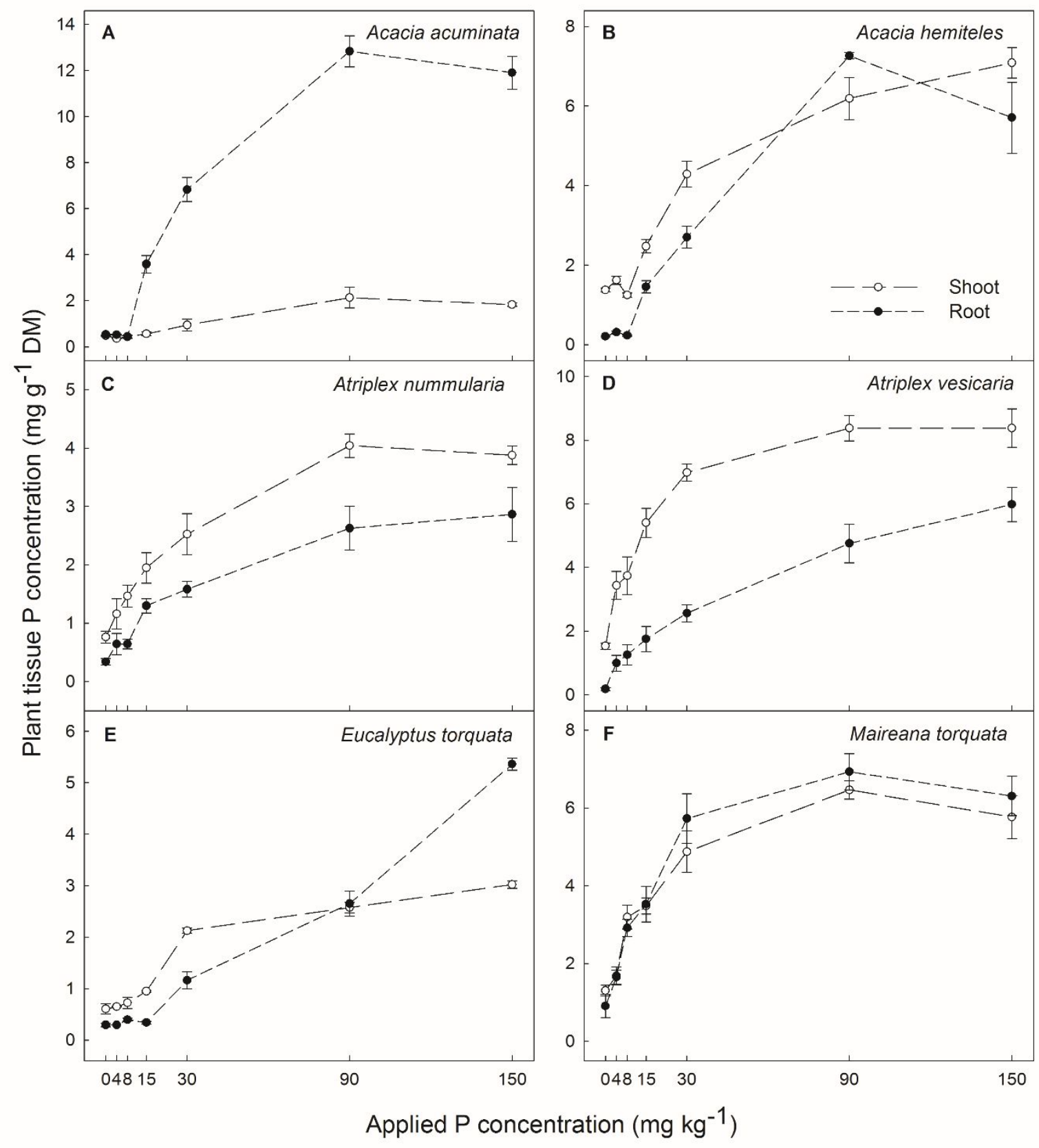


Williams et al.

Page 24

$1 \quad$ Figure 3.

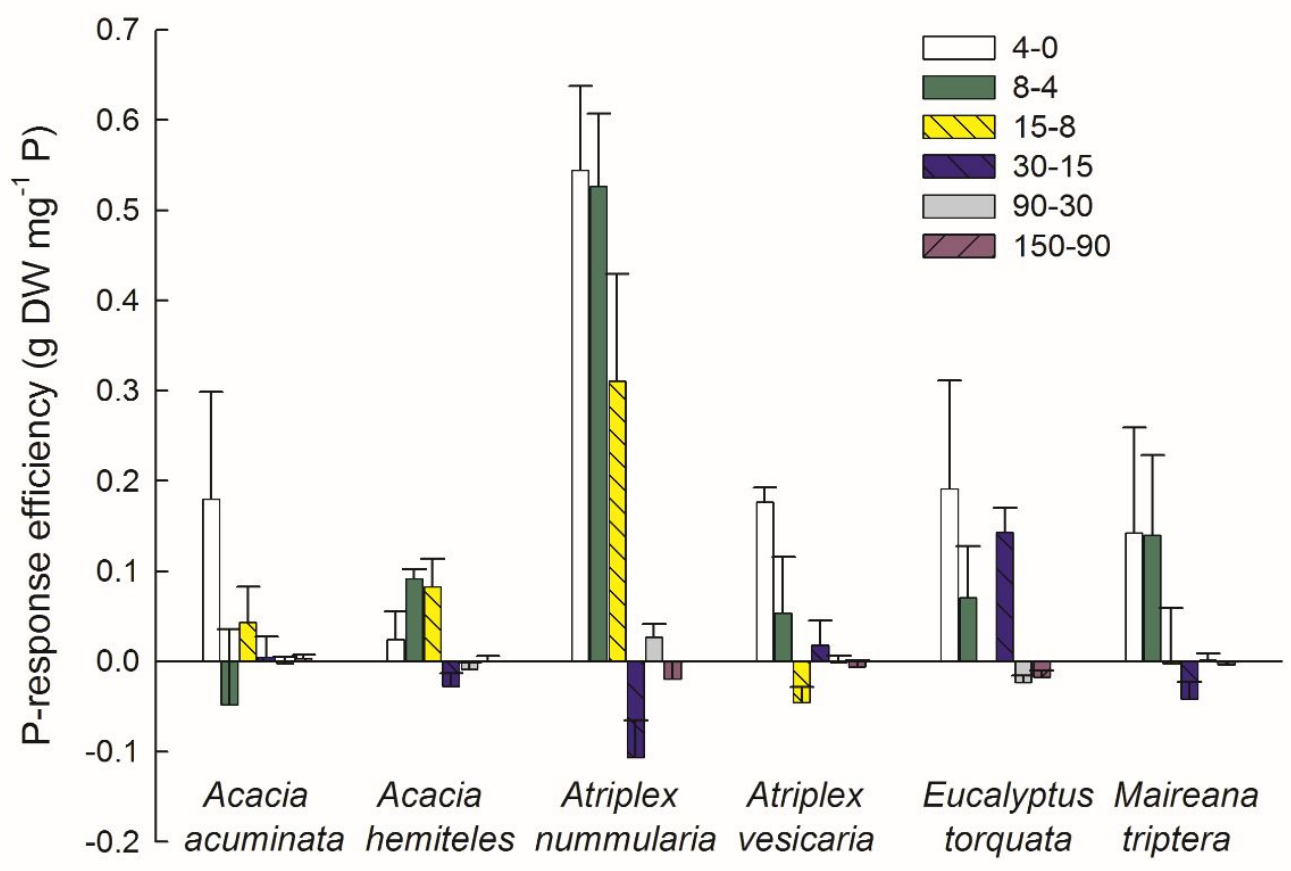

2 


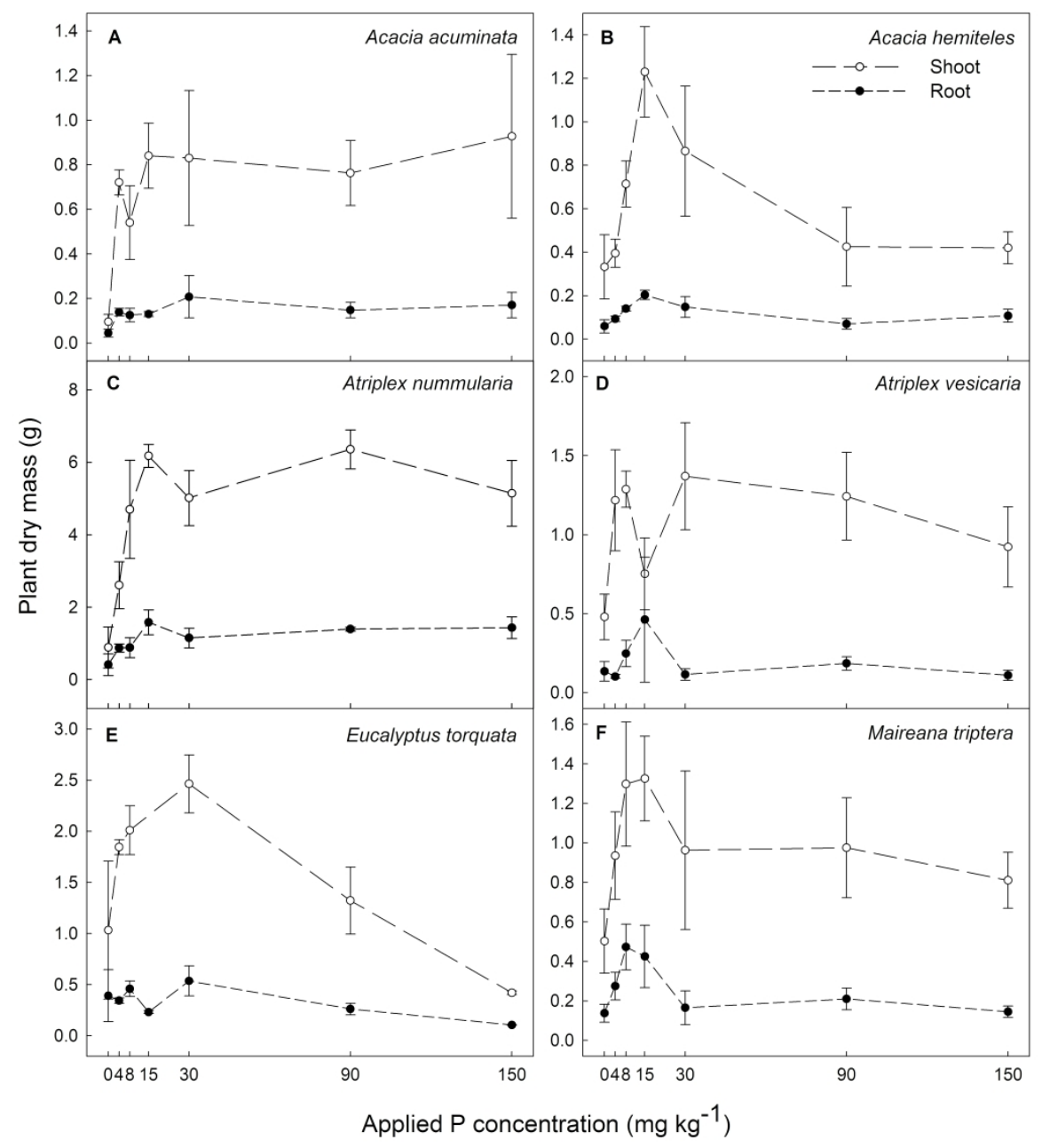

Fig. 1. The effect of a range of external P concentrations on dry mass of six woody species from the Great Western Woodlands grown for 136 days in washed river sand at a range of external soil P concentrations, $n=4+/$ - standard error of the mean.

$863 \times 1117 \mathrm{~mm}(150 \times 150 \mathrm{DPI})$ 


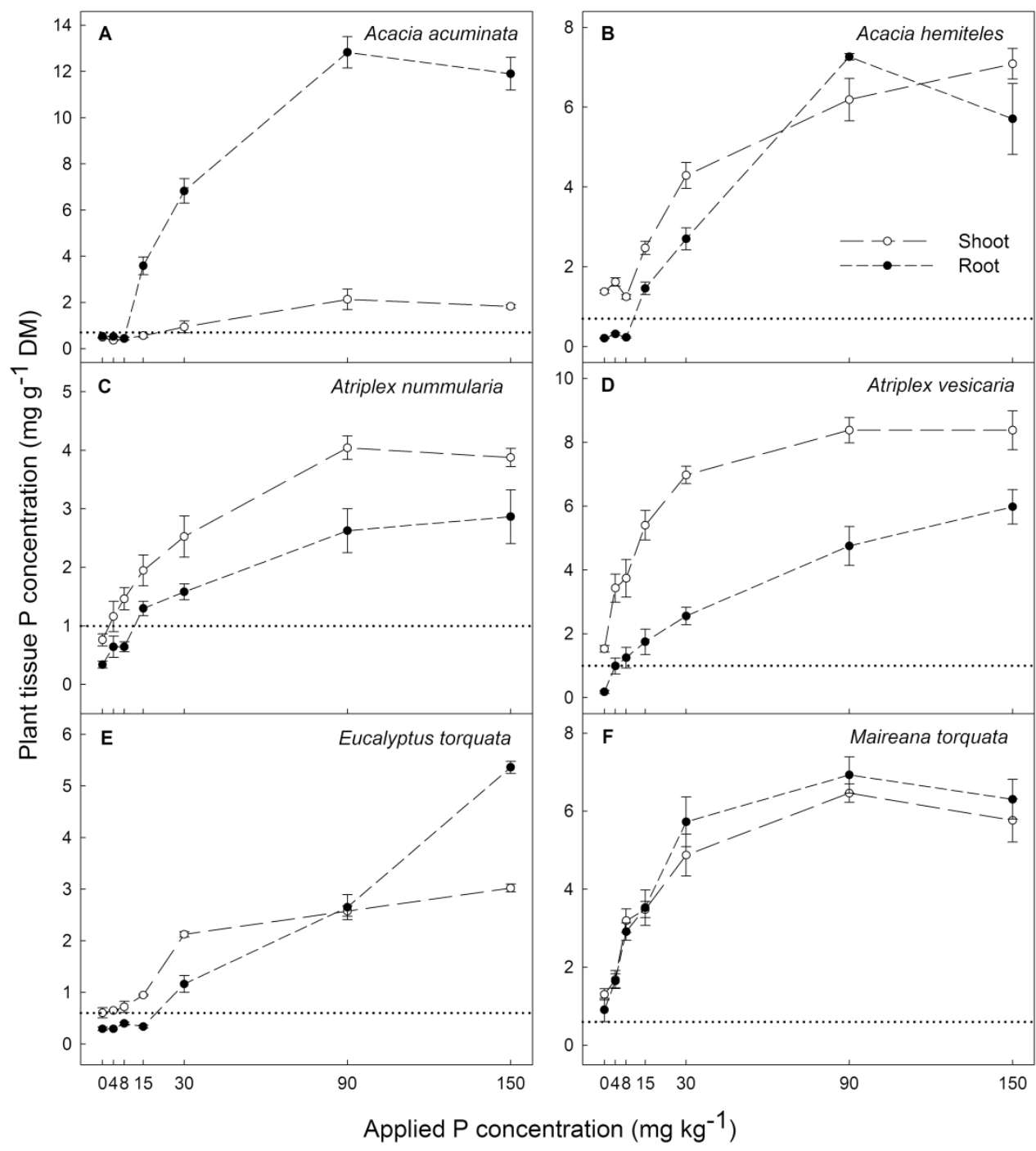

Fig.2. Comparison of root and shoot $P$ concentrations for six woody species from the Great Western Woodlands grown for 136 days in washed river sand at a range of external $P$ concentrations, $n=4+/-$ standard error of the mean. Dotted lines parallel to the $x$-axis represent phosphorus concentrations in shoot tissue for the plant families as reported in the natural flora of south west Western Australia (Foulds 1993).

$849 \times 956 \mathrm{~mm}(150 \times 150 \mathrm{DPI})$ 


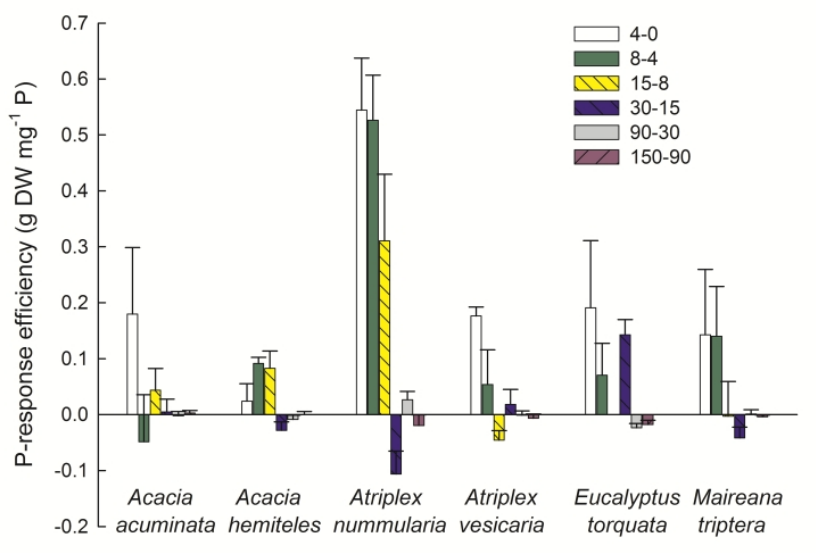

Fig.3. Phosphorus-response efficiency (yield response per unit of applied $\mathrm{P}$ ) measured for six $\mathrm{P}$-application ranges (0-4, 4-8, 8-15, 15-30, 30-90 and 90-150 mg $P$ kg-1 sand) for six woody species from the Great Western Woodland, $n=4+/-$ standard error of the mean.

$846 \times 1095 \mathrm{~mm}(150 \times 150 \mathrm{DPI})$ 


\begin{tabular}{|c|c|c|c|c|}
\hline Species & Genus & $\begin{array}{l}\text { Seed mass } \\
(\mathrm{mg})\end{array}$ & $\begin{array}{l}\text { Seed } P \\
\text { concentration } \\
\left(\mathrm{mg} \mathrm{g}^{-1} \mathrm{DM}\right)\end{array}$ & $\begin{array}{l}\text { Growth } \\
\text { form }\end{array}$ \\
\hline $\begin{array}{l}\text { Acacia acuminata } \\
\text { Benth. }\end{array}$ & Fabaceae & 15.2 & 2.1 & Shrub or tree \\
\hline $\begin{array}{l}\text { Acacia hemiteles } \\
\text { Benth. }\end{array}$ & Fabaceae & 22.1 & 1.9 & Shrub \\
\hline $\begin{array}{l}\text { Atriplex nummularia } \\
\text { Lindl. }\end{array}$ & Chenopodiaceae & 6.86 & 0.7 & Shrub \\
\hline $\begin{array}{l}\text { Atriplex vesicaria } \\
\text { Heward ex Benth. }\end{array}$ & Chenopodiaceae & 5.77 & 0.7 & Shrub \\
\hline $\begin{array}{l}\text { Eucalyptus torquata } \\
\text { Luehm. }\end{array}$ & Myrtaceae & 5.18 & 0.6 & Tree \\
\hline $\begin{array}{l}\text { Maireana triptera } \\
\text { (Benth.) Paul G. }\end{array}$ & Chenopodiaceae & 12.54 & 7 & Shrub \\
\hline Wilson & & & & \\
\hline
\end{tabular}




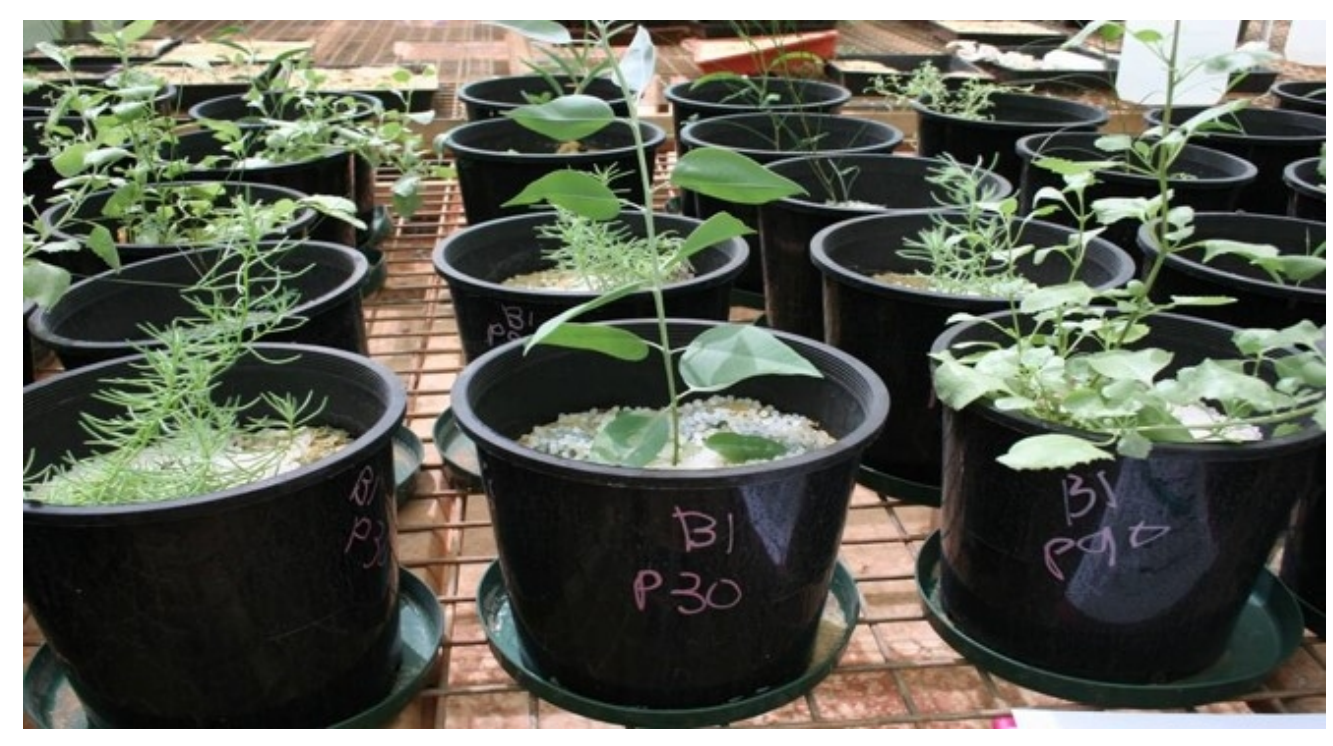

$112 \times 61 \mathrm{~mm}(150 \times 150 \mathrm{DPI})$ 